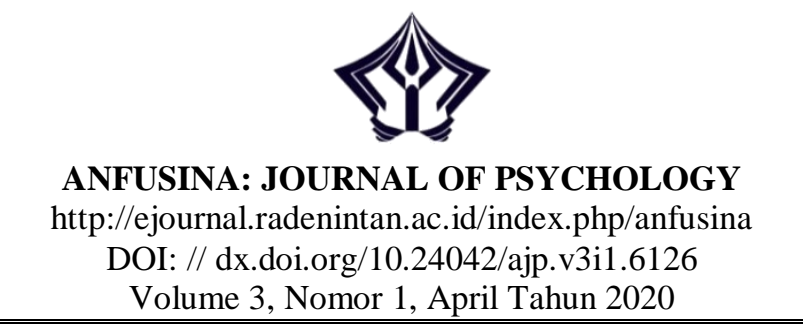

\title{
Hubungan Antara Kepribadian Big Five Dengan Perilaku Prososial Mahasiswa
}

\author{
Citra Wahyuni \\ UIN Raden Intan Lampung \\ citrawahyuni16@gmail.com \\ Sisca Permatasari \\ UIN Raden Intan Lampung \\ siscapermatasari@gmail.com
}

\begin{abstract}
Prosocial behavior is an individual voluntary action in the absence of coercion from outside, desires to provide assistance to others without expecting anything in return for getting rewarded and even at risk for those who help. Big five personality is a personality that explains the relationship between one's beliefs about something obtained from an individual's mind is very influential in the form of an individual's actions. This study aims to determine the relationship between big five personality with prosocial behavior in Islamic Psychology students. The hypothesis in this study, the relationship of each of the five dimensions of the Big Five personality with prosocial behavior. The subjects of this study were students of the Islamic Psychology Faculty of Ushuluddin and Religious Studies of UIN Raden Intan Lampung class of 2016, 2017 and 2018 with a sample of 100 students taken using disproportional stratified random sampling techniques. The tools used in data collection using a prosocial behavior scale consisting of 29 items $(\alpha=0.899)$ and the big five personality scale consisting of 27 items $(\alpha=0.874)$.Data analysis used was multiple regression analysis. The results showed that two of the five dimensions
\end{abstract}


of big five personality had a significant relationship with prosocial behavior, namely openness and agreeableness. The dimensions of personality conscientiousness with regression coefficient 0.604 ( $p=$ 0.193) did not have a significant relationship with prosocial behavior. The dimension of extraversion personality with regression coefficient -0.666 $(p=0.319)$ did not have a significant relationship with prosocial behavior. The dimensions of neuroticism personality with regression coefficient $0.629(p=0.145)$ did not have a significant relationship with prosocial behavior.

\begin{abstract}
Abstrak
Perilaku prososial adalah tindakan individu secara sukarela dengan tidak adanya paksaan dari luar, berkeinginan untuk memberikan bantuan kepada orang lain tanpa mengharapkan balasan untuk mendapatkan imbalan dan bahkan beresiko bagi orang yang menolong. Kepribadian big five adalah kepribadian yang menjelaskan hubungan antara keyakinan seseorang tentang sesuatu yang didapatkan dari pikiran individu sangat berpengaruh dalam bentuk tindakan seorang individu. Penelitian ini bertujuan untuk mengetahui hubungan antara kepribadian big five dengan perilaku prososial pada mahasiswa Psikologi Islam. Hipotesis dalam penelitian ini, adanya hubungan masing-masing dari lima dimensi kepribadian big five dengan perilaku prososial. Subjek penelitian ini adalah mahasiswa program studi Psikologi Islam Fakultas Ushuluddin dan Studi Agama UIN Raden Intan Lampung angkatan 2016, 2017 dan 2018 dengan sampel 100 mahasiswa Psikologi Islam yang diambil menggunakan teknik disproportional stratified random sampling. Alat yang digunakan dalam pengumpulan data menggunakan skala perilaku prososial yang terdiri dari 40 aitem $(\alpha=0,899)$ dan skala kepribadian big five yang terdiri dari 35 aitem $(\alpha=0,874)$ Analisis data yang digunakan adalah analisis regresi berganda. Hasil penelitian menunjukkan dua dari lima dimensi kepribadian big five memiliki hubungan yang signifikan dengan perilaku prososial yaitu openness dan agreeableness. Dimensi kepribadian conscientiousness dengan koofisien regresi $0,604(p=$ 0,193 ) tidak memiliki hubungan yang signifikan dengan perilaku prososial. Dimensi kepribadian extraversion dengan koofisien regresi $0,666(\mathrm{p}=0,319)$ tidak memiliki hubungan yang signifikan dengan perilaku prososial. Dimensi kepribadian neuroticism dengan koofisien regresi $0,629(\mathrm{p}=0,145)$ tidak memiliki hubungan yang signifikan dengan perilaku prososial.
\end{abstract}

Keywords = Big Five Personality, Prosocial Behavior 


\section{Pendahuluan}

Mahasiswa adalah individu yang berada pada fase dewasa awal, yaitu berada pada masa rentang usia 18 tahun -40 tahun. Masa dewasa ini merupakan periode penyesuaian diri mahasiswa terhadap kehidupan baru atau lingkungan baru dengan harapan mahasiswa dapat bersosialisasi dengan baik. Selain itu orang dewasa awal juga diharapkan mampu menyesuaikan diri individu secara mandiri (Hurlock, 2004). Mahasiswa adalah seseorang yang sedang dalam proses menimba ilmu dan menjalani pendidikan pada salah satu perguruan tinggi yang terdiri dari akademik, politeknik, sekolah tinggi, institut dan universitas (Hartaji, 2012).

Pemerintah mengatur penyelenggaraan perguruan tinggi (PT) dengan salah satunya menerbitkan undang - undang (UU) No 12 Tahun 2012 dalam pasal 4 dan pasal 5. Pada pasal 4, Pendidikan Tinggi berfungsi untuk mengembangkan mahasiswa menjadi individu yang inovatif, responsif, kreatif, terampil, kooperatif, serta dapat mengembangkan ilmu pengetahuan dan teknologi dengan memperhatikan dan menerapkan nilai Humaniora. Selanjutnya pada pasal 5, mahasiswa yang belajar pada PT diharapkan memiliki akhlak mulia, mampu berkomunikasi dengan baik, kreatif, mandiri, terampil, kompeten dan berbudaya untuk kepentingan bangsa dan negara. Mahasiswa juga diharapkan dapat mengimplementasikan ilmunya untuk kemajuan peradapan dan kesejahteraan manusia yang terwujud dalam pengabdikan kepada masyarakat berbasis penalaran dan karya penelitian.

Perilaku juga ditujukan untuk mengubah keadaan fisik atau psikologis orang lain, yaitu dari yang tadinya kurang baik menjadi lebih baik, dalam arti secara material maupun psikologis, tetapi tidak memiliki keuntungan bagi individu yang menolong hal tersebut disebut perilaku prososial. Sejalan dengan hal tersebut, Sears (2009) menyatakan bahwa perilaku prososial merupakan suatu tindakan yang dilakukan untuk menolong orang lain dengan sepenuh hati, tanpa mengharapkan suatu apapun bagi diri penolong itu sendiri. Lebih lanjut, Baron dan Byrne (2005) mengatakan bahwa perilaku prososial adalah tindakan individu secara sukarela dengan tidak adanya paksaan dari luar, berkeinginan untuk memberikan bantuan kepada orang lain tanpa mengharapkan balasan untuk mendapatkan imbalan.

Peneliti melakukan wawancara kepada salah satu seorang mahasiswa perwakilan himpunan mahasiswa jurusan (HMJ) Psikologi Islam, mengenai partisipasi mahasiswa dalam perilaku menolong dan 
berbagi. Contohnya bakti sosial untuk membantu masyarakat yang terkena musibah bencana alam. Menurut perwakilan himpunan mahasiswa jurusan (HMJ) tersebut, setelah terjadinya bencana alam tsunami selat sunda yang terjadi pada tanggal 22 Desember 2018 di Lampung Selatan, mahasiswa Psikologi Islam bergerak untuk melakukan penggalangan dana. Kegiatan tersebut dilakukan oleh 58 orang mahasiswa dari 468 mahasiswa Psikologi Islam. Jumlah mahasiswa yang ikut serta dalam kegiatan tersebut hanya sekitar $12 \%$ dari mahasiswa Psikologi Islam secara keseluruhan. Hasil wawancara peneliti dengan perwakilan himpunan mahasiswa jurusan (HMJ) mengapa yang berpartisipasi hanya sedikit dikarenakan pada saat itu masa perkuliahan sudah mulai berakhir sehinga tidak banyak mengikuti kegiatan tersebut karena mayoritas mahasiswa adalah perantau jadi yang banyak mengikuti kegiatan tersebut mahasiswa yang berada di daerah Bandar Lampung. Fenomena tersebut menunjukkan bahwa perilaku menolong di kalangan mahasiswa Prodi Psikologi Islam masih tergolong rendah.

Rendahnya perilaku prososial pada mahasiswa Prodi Psikologi Islam menunjukkan bahwa masih ada kesenjangan antara tujuan pembelajaran dalam hal sikap dengan aktualisasi sikap dan perilaku mahasiswa. Sebagaimana yang tercantum pada kurikulum AP2TPI bahwa mahasiswa Psikologi dituntut memiliki kepekaan, empati, dan kesediaan untuk menolong masyarakat sekitarnya.

Shaffer (2000) mengatakan bahwa terdapat berbagai macam bentuk perilaku prososial, seperti berbagi pada orang yang membutuhkan, menolong orang yang membutuhkan pertolongan kita, bekerjasama dengan orang lain atau menolong seseorang untuk mencapai suatu tujuan. Kenrick (2010) mengungkapan bahwa setiap individu memiliki suatu tujuan dari tindakan prososial yang dilakukan seperti untuk meningkatkan kesejahteraan bagi setiap individu, menaikkan status sosial, mengatur persepsi tentang diri kita sendiri, serta mengatur perasaan yang mudah berubah - ubah dan emosi yang tidak menentu.

Mussen (2002) mengemukakan tentang beberapa aspek perilaku prososial yaitu: berbagi (sharing), menolong (helping), berdermawan (donating), kerja sama (cooperating), dan jujur (honesty). Berbagi (sharing) adalah menceritakan permasalahan yang sedang kita alami dengan orang lain baik cerita yang menggembirakan maupun cerita sedih. Menolong (helping) adalah suatu tindakan untuk menolong orang lain yang sedang berada dalam bahaya atau mengalami kesulitan. Berdermawan (donating) adalah suatu tindakan yang dilakukan untuk 
memberikan secara sukarela berupa barang maupun bukan kepada orang lain yang membutuhkan. Kerjasama (cooperating) adalah kesediaan individu untuk bekerja sama dengan orang lain agar tercapai suatu tujuan yang di inginkan. Terakhir, jujur (honesty) adalah suatu kesusaian sikap antara perkataan dan perbuatan yang sebenarnya, kesediaan untuk tidak berbuat curang atau berbohong pada orang lain.

Perilaku prososial dipengaruhi faktor-faktor karakteristik situasional dan faktor-faktor karakteristik personal. Faktor-faktor karakteristik situasional, yaitu kehadiran orang lain, pengorbanan yang harus dikeluarkan oleh individu, pengalaman dan suasana hati, kejelasan stimulus, adanya norma-norma sosial, hubungan antara calon penolong dengan korban. Lebih lanjut, yang dimaksud dengan faktor personal adalah karakteristik kepribadian. Kepribadian seseorang adalah salah satu faktor yang dapat membuat orang mudah tergerak hatinya untuk bertindak melakukan perilaku prososial (Dayakisni \& Hudaniah, 2009).

Menurut Feist dan Feist (2009) kepribadian didefinisikan sebagai bentuk watak individu yang relatif permanen dan karakter yang unik dimana keduanya memiliki konsistensi dan keunikan pada perilaku individu. Salah satu teori kepribadian yang sering digunakan untuk menjelaskan kepribadian seseorang adalah The Big Five Personality.

Caprara dan Cervone (2000) mengatakan bahwa Teori kepribadian big five adalah teori kepribadian yang menjelaskan hubungan antara keyakinan seseorang tentang sesuatu yang didapatkan dari pikiran individu sangat berpengaruh dalam bentuk tindakan seorang individu. Pada Teori The Big Five Personality terdapat lima dimensi kepribadian, yaitu Extraversion (E), Agreeableness (A), Conscientiousness (C), Neuroticism (N), dan Openness (O).

Openness yang didefinisikan sebagai dimensi kepribadian dengan daya imajinasi yang tinggi, menyukai hal yang baru tanpa meniru atau mengikuti seseorang, memiliki mental yang kuat dan pengalaman hidup yang saling berhubungan dan saling tergantung, serta berani mencoba hal-hal baru diluar kebiasaannya. Conscientiousness didefinisikan sebagai dimensi kepribadian seorang yang dapat dipercaya, pekerja keras, disiplin, tepat waktu, teliti, dan seorang yang tekun (Pervin, Cervone \& John, 2010).

Extraversion didefinisikan sebagai dimensi kepribadian yang bersemangat terhadap dunia sosial dan material serta memiliki watak mudah bergaul, aktif, banyak berbicara, optimis, mudah menyesuaikan 
diri pada lingkungan baru memiliki komunikasi dengan baik dan memiliki emosi yang positif (Pervin, Cervone \& John, 2010).

Agreeableness didefinisikan sebagai dimensi kepribadian yang berorientasi prososial pada orang lain serta memiliki watak altruisme, lemah lembut dan mudah percaya dengan orang lain, dapat dipercaya, mudah memaafkan orang dan terus terang terhadap orang lain. Neuroticism didefinisikan sebagai kepribadian dengan emosi negatif sehingga rentan mengalami kecemasan, emosional, depresi, sedih, agresif, dan lain-lain (Pervin, Cervone \& John, 2010).

Penelitian yang dilakukan oleh Nugrahini (2016) mengenai perilaku prososial ditinjau dari big five personality menunjukkan bahwa individu yang memiliki skor tinggi pada dimensi opennes to experience akan cenderung memiliki rasa ingin tahu yang tinggi, ketertarikan luar, kreatif, original, imajinatif, tidak ketinggalan zaman. Oleh karenanya, individu tersebut berani untuk melakukan hal - hal baru seperti menolong sesama tanpa melihat perbedaan ras. Individu dengan skor tinggi pada dimensi conscientiouness memiliki harga diri yang tinggi, sehingga individu akan melakukan perilaku prososial.

Individu yang memiliki skor tinggi pada dimensi extraversion akan lebih suka menolong dan dapat lebih mudah melakukan perilaku prososial. Individu yang memiliki skor tinggi pada dimensi agreeableness memiliki empati lebih terhadap orang lain dan menaruh perhatian pada orang lain yang sedang kesusahan atau kesulitan, sehingga individu akan menunjukkan perilaku prososial. Individu yang memiliki skor rendah pada dimensi neouroticism tidak akan menghindari perilaku prososial dan individu tidak takut atau tidak akan menghindar untuk berhubungan dengan orang lain (Nugrahini, 2016).

\section{Metode Penelitian}

Penelitian ini merupakan jenis penelitian kuantitatif dengan desain korelasional non eksperimental. Subjek penelitian berjumlah sebanyak 100 orang mahasiswa Prodi Psikologi Islam Fakultas Ushuluddin dan Studi Agama UIN Raden Intan Lampung yang berasal dari angkatan 2016, 2017, dan 2018. Subjek dalam penelitian ini diambil dengan teknik disproportional stratified random sampling, yakni teknik pengambilan sampel pada populasi yang berstrata tetapi kurang proporsional. Pengumpulan data dalam penelitian ini dilakukan dengan menyebarkan tiga buah skala, yaitu: 


\section{a. Skala Perilaku Prososial}

Pada penelitian ini peneliti menggunakan skala perilaku prososial yang disusun oleh peneliti sendiri. Peneliti membuat pernyataan sejumlah 40 aitem dengan menggunakan skala perilaku prososial berdasarkan teori Eisenberg dan Mussen (1989) yaitu berbagi (sharing), menolong (helping), berdermawan (donating), kerja sama (cooperating), jujur (honesty). Skala perilaku prososial disusun dengan empat respon jawaban, yaitu SS (Sangat Setuju), S (Setuju), TS (Tidak Setuju), dan STS (Sangat Tidak Setuju), dengan skor masing - masing jawaban 1,2,3,4 untuk favorable, sedangkan aspek unfavorable bergerak dari 4,3,2,1.

Hasil perhitungan validitas dan reliabilitas skala perilaku prososial dengan 40 aitem, yang telah diuji coba pada 40 subjek memperoleh 29 aitem valid dan 11 aitem yang gugur. Aitem yang valid tersebut memiliki korelasi aitem-total berkisar 0,256 sampai 0,731. Koefisien reliabilitas alpha (cronbach's alpha) pada skala perilaku prososial memiliki nilai 0,899 yang berarti aitem skala tersebut reliabel.

\section{b. Skala Kepribadian Big Five}

Pada penelitian ini peneliti menggunakan skala big five inventory yang mengunakan adaptasi skala BFI (Big Five Inventory). Peneliti membuat pernyataan sejumlah 35 aitem dengan menggunakan skala kepribadian big five yang disusun berdasarkan teori Costa dan McCrae (1992) yang disusun oleh John \& Srivasta (1999) dengan menggunakan lima dimensi kepribadian, yaitu Extraversion (E), Agreeableness (A), Conscientiousness (C), Neuroticism (N), dan Openness (O). Skala kepribadian big five disusun dengan empat respon jawaban, yaitu SS (Sangat Setuju), S (Setuju), TS (Tidak Setuju), dan STS (Sangat Tidak Setuju), dengan skor masing - masing jawaban 1,2,3,4 untuk favorable, sedangkan aspek unfavorable bergerak dari 4,3,2,1.

Setelah dilakukan perhitungan validitas dan reabilitas dari 35 aitem yang diujikan pada 40 responden dapat diperoleh 27 aitem valid dan 8 aitem gugur. Aitem valid yang diperoleh memiliki korelasi aitem-total yang berkisar 0,265 sampai 0,654. Koefesien reliabilitas alpha croncbach pada skala kepribadian big five memiliki nilai 0.874 yang berarti aitem tersebut reliabel. 


\section{Hasil dan Pembahasan}

\section{Kategorisasi Data}

Kategorisasi variabel bertujuan menempatkan individu dalam kelompok-kelompok yang terpisah secara berjenjang menurut suatu komitmen berdasarkan atribut yang telah diukur. Setelah kategorisasi tersebut didapatkan, maka akan diperoleh nilai presentasi kategorisasi untuk masing-masing variabel.

\section{a. Kategorisasi Perilaku Prososial}

Pada tabel dibawah ini merupakan tabel yang menunjukkan sebuah variabel perilaku prososial. Skala terdiri dari 29 pernyataan yang berhubungan dengan perilaku prososial. Peneliti membagi tiga kategorisasi pada variabel perilaku prososial yaitu tinggi, rendah, dan sedang sebagaimana yang tertera dalam tabel berikut ini:

Tabel 1.

Kategorisasi Perilaku Prososial

\begin{tabular}{cccc}
\hline Kategori & Rentan Skor & Frekuensi & Persen (\%) \\
\hline Tinggi & $87 \leq \mathrm{X}$ & 82 & $82 \%$ \\
Sedang & $58 \leq \mathrm{X}<87$ & 18 & $18 \%$ \\
Rendah & $\mathrm{X}<58$ & 0 & $0 \%$ \\
& Jumlah & 100 & $100 \%$ \\
\hline
\end{tabular}

Berdasarkan tabel di atas, dapat di ketahui bahwa kategorisasi perilaku prososial, terbagi menjadi tiga kategori yaitu kategori tinggi dengan rentang skor $87 \leq \mathrm{X}$ dapat diperoleh oleh 82 mahasiswa yang memiliki perilaku prososial dengan persentase $82 \%$. Kategori sedang dengan rentang skor $58 \leq X<87$ diperoleh oleh 18 mahasiswa dengan persentase 18\%. Sedangkan pada kategorisasai rendah dengan rentang skor $\mathrm{X}<58$ tidak diperoleh oleh mahasiswa dengan persentase $0 \%$, sedangkan skor rendah tidak diperoleh oleh mahasiswa Psikologi Islam. Hal tersebut menunjukan bahwa perilaku prososial pada mahasiswa Psikologi Islam di UIN Raden Intan Lampung Fakultas Ushuluddin dan Studi Agama termasuk kategori tinggi. 


\section{b. Dimensi kepribadian openness}

Pada tabel di bawah ini merupakan tabel yang menunjukan sebuah variabel kepribadian big five dengan skala yang terdiri dari 27 pernyataan yang berhubungan dengan kepribadian big five dalam hal ini dibagi menjadi tiga kategori sebagaimana telah dijelaskan sebelumnya, yaitu tinggi, sedang dan rendah.

Pada skala kepribadian big five dimensi openness terdiri dari empat pernyataan openness. Berikut ini adalah hasil kategorisasi yang diperoleh pada dimensi openness:

\section{Tabel 2.}

Kategorisasi Dimensi Kepribadian Openness

\begin{tabular}{cccc}
\hline Kategori & Rentan Skor & Frekuensi & Persen (\%) \\
\hline Tinggi & $12 \leq \mathrm{X}$ & 82 & $82 \%$ \\
Sedang & $8 \leq \mathrm{X}<12$ & 18 & $18 \%$ \\
Rendah & $\mathrm{X}<8$ & 0 & $0 \%$ \\
Jumlah & & 100 & $100 \%$ \\
\hline
\end{tabular}

Berdasarkan tabel di atas, dapat di ketahui bahwa mahasiswa Psikologi Islam yang termasuk kategori openness tinggi dengan rentang skor $12 \leq \mathrm{X}$ dapat diperoleh oleh 82 mahasiswa dengan persentase sebesar $82 \%$. Kategori sedang dengan rentang skor $8 \leq$ $\mathrm{X}<12$ diperoleh oleh mahasiswa 18 dengan persentase $18 \%$. Sedangkan pada kategori rendah dengan skor $\mathrm{X}<8$ tidak diperoleh oleh mahasiswa dengan persentase $0 \%$. Hal tersebut menunjukan bahwa mahasiswa Psikologi Islam di UIN Raden Intan Lampung Fakultas Ushuluddin dan Studi Agama termasuk kategori sedang.

\section{c. Dimensi kepribadian conscientiousness}

Pada skala kepribadian big five dimensi conscientiousness terdiri dari lima pernyataan conscientiousness. Berikut ini adalah hasil kategorisasi yang diperoleh pada dimensi conscientiousness: 
Tabel 3.

Kategorisasi Dimensi Kepribadian Conscientiousness $\begin{array}{llll}\text { Kategori } & \text { Rentan Skor } & \text { Frekuensi } & \text { Persen (\%) }\end{array}$

\begin{tabular}{cccc}
\hline Tinggi & $15 \leq \mathrm{X}$ & 65 & $65 \%$ \\
Sedang & $10 \leq \mathrm{X}<15$ & 35 & $35 \%$ \\
Rendah & $\mathrm{X}<10$ & 0 & $0 \%$ \\
Jumlah & & 100 & $100 \%$ \\
\hline
\end{tabular}

Berdasarkan tabel di atas, dapat di ketahui bahwa mahasiswa Psikologi Islam yang termasuk kategori conscientiousness tinggi dengan rentang skor $15 \leq \mathrm{X}$ dapat diperoleh oleh 65 mahasiswa dengan persentase sebesar $65 \%$. Kategori sedang dengan rentang skor $10 \leq \mathrm{X}<15$ diperoleh oleh mahasiswa 35 dengan persentase $36 \%$. Sedangkan pada kategori rendah dengan skor $X<10$ tidak diperoleh oleh mahasiswa dengan persentase 0\%. Hal tersebut menunjukan bahwa mahasiswa psikologi di UIN Raden Intan Lampung Fakultas Ushuluddin dan Studi Agama termasuk kategori Tinggi

\section{d. Dimensi kepribadian extraversion}

Pada skala kepribadian big five dimensi extraversion terdiri dari empat pernyataan extraversion. Berikut ini adalah hasil kategorisasi yang diperoleh pada dimensi extraversion:

Tabel 4.

Kategorisasi Dimensi Kepribadian Extraversion

\begin{tabular}{rccc}
\hline Kategori & Rentan Skor & Frekuensi & Persen (\%) \\
\hline Tinggi & $12 \leq \mathrm{X}$ & 100 & $100 \%$ \\
Sedang & $8 \leq \mathrm{X}<12$ & 0 & $0 \%$ \\
Rendah & $\mathrm{X}<8$ & 0 & $0 \%$ \\
Jumlah & & 100 & $100 \%$ \\
\hline
\end{tabular}

Berdasarkan tabel di atas, dapat di ketahui bahwa pada mahasiswa Psikologi Islam yang termasuk kategori extraversion tinggi dengan rentang skor $12 \leq \mathrm{X}$ dapat diperoleh oleh 100 mahasiswa dengan persentase sebesar $100 \%$. Kategori sedang dengan rentang skor $8 \leq \mathrm{X}<12$ tidak diperoleh oleh mahasiswa dengan persentase $0 \%$. Sedangkan pada kategori rendah dengan 
skor $\mathrm{X}<8$ tidak diperoleh oleh mahasiwa dengan persentase $0 \%$. Hal tersebut menunjukan bahwa mahasiswa psikologi di UIN Raden Intan Lampung Fakultas Ushuluddin dan Studi Agama termasuk kategori Tinggi.

\section{e. Dimensi kepribadian agreeableness}

Pada skala kepribadian big five dimensi agreeableness terdiri dari delapan pernyataan agreeableness. Berikut ini adalah hasil kategorisasi yang diperoleh pada dimensi agreeableness:

\section{Tabel 5.}

Kategorisasi Dimensi Kepribadian Agreeableness

\begin{tabular}{rccc}
\hline Kategori & Rentan Skor & Frekuensi & Persen (\%) \\
& & & \\
\hline Tinggi & $24 \leq \mathrm{X}$ & 80 & $80 \%$ \\
Sedang & $16 \leq \mathrm{X}<24$ & 20 & $20 \%$ \\
Jumlah & 100 & $100 \%$ & $0 \%$ \\
\hline
\end{tabular}

Berdasarkan tabel di atas, dapat di ketahui bahwa pada mahasiswa Psikologi Islam yang termasuk kategori agreeableness tinggi dengan rentang skor $24 \leq \mathrm{X}$ dapat diperoleh oleh 80 mahasiwa dengan persentase sebesar $80 \%$. Kategori sedang dengan rentang skor $16 \leq X<24$ diperoleh oleh 20 mahasiswa dengan persentase $20 \%$. Sedangkan pada kategori rendah dengan skor $\mathrm{X}<$ 16 tidak diperoleh oleh mahasiswa dengan persentase $0 \%$. Hal tersebut menunjukan bahwa mahasiswa psikologi di UIN Raden Intan Lampung Fakultas Ushuluddin dan Studi Agama termasuk kategori Tinggi.

\section{f. Dimensi kepribadian neuroticism}

Pada skala kepribadian big five dimensi neuroticism terdiri dari enam pernyataan neuroticism. Berikut ini adalah hasil kategorisasi yang diperoleh pada dimensi neuroticism: 
Tabel 6.

Kategorisasi Dimensi Kepribadian Neuroticism

\begin{tabular}{cccc}
\hline Kategori & Rentan Skor & Frekuensi & Persen (\%) \\
\hline Tinggi & $18 \leq \mathrm{X}$ & 75 & $75 \%$ \\
Sedang & $12 \leq \mathrm{X}<18$ & 25 & $25 \%$ \\
Rendah & $\mathrm{X}<12$ & 0 & 0 \\
Jumlah & 100 & $100 \%$ \\
\hline
\end{tabular}

Berdasarkan tabel di atas, dapat di ketahui bahwa pada mahasiswa Psikologi Islam yang termasuk kategori neuroticism tinggi dengan rentang skor $18 \leq \mathrm{X}$ dapat diperoleh oleh 75 mahasiswa dengan persentase sebesar $75 \%$. Kategori sedang dengan rentang skor $12 \leq \mathrm{X}<18$ diperoleh oleh 25 mahasiswa dengan persentase $25 \%$. Sedangkan pada kategori rendah dengan skor $\mathrm{X}<12$ tidak diperoleh oleh mahasiswa dengan persentase $0 \%$. Hal tersebut menunjukan bahwa mahasiswa psikologi di UIN Raden Intan Lampung Fakultas Ushuluddin dan Studi Agama termasuk kategori Tinggi

\section{Hasil Uji Hipotesis}

Perhitungan untuk uji hipotesis dilakukan dengan metode analisis regresi berganda yang dihitung menggunakan bantuan program komputer SPSS versi 22.0 for windows. Dalam hal ini, terdapat tiga hal yang harus diperhatikan. Pertama, besaran $R$ square sumbangan efektif untuk mengetahui berapa persen (\%) varians variabel dependen yang dijelaskan oleh variabel independen. Kedua, apakah secara keseluruhan variabel independen berpengaruh secara signifikan terhadap variabel dependen.

Terakhir, memperhatikan siginfikans tidaknya koefisien regresi dari masing-masing variabel independen. Langkah pertama, peneliti melihat besaran $R$-square untuk mengetahui berapa persen (\%) varians variabel dependen yang dijelaskan oleh variabel independen. Untuk tabel $R$-square dapat dilihat pada tabel berikut ini: 
Tabel 7.

R-Square Model Summary

\begin{tabular}{ccccc}
\hline Model & R & R-Square & $\begin{array}{c}\text { Adjusted R } \\
\text { Square }\end{array}$ & $\begin{array}{c}\text { Std Error of the } \\
\text { Estimate }\end{array}$ \\
\hline 1 & $0.616^{\mathrm{a}}$ & 0.380 & 0.347 & 6.430 \\
\hline
\end{tabular}

Hasil analisis data pada tabel di atas memperoleh nilai $R$-Square $=0,380$. Oleh karenanya, dapat diinterpretasikan bahwa variabel bebas memiliki pengaruh sebesar 38\% terhadap variabel terikat dan $62 \%$ sisanya dipengaruhi oleh variabel lain diluar penelitian ini.

Langkah kedua, peneliti melakukan uji $\mathrm{F}$ untuk menganalisis pengaruh dari keseluruhan variabel independen. Adapun hasil uji $\mathrm{F}$ dapat dilihat pada tabel dibawah ini:

Tabel 8.

Tabel Anova

\begin{tabular}{cccccc}
\hline Model & Sum of Squares & Df & Mean Square & F & Sig \\
\hline Regression & 2379,297 & 5 & 475,859 & 11,510 &, $000^{\mathrm{a}}$ \\
Residual & 3886,093 & 94 & 41,341 & & \\
Total & 6265,390 & 99 & & & \\
\hline
\end{tabular}

Dari tabel di atas, dapat dilihat bahwa nilai p pada kolom paling kanan adalah 0,000 atau $\mathrm{p}=0,000$ dengan nilai $\mathrm{p}<0,05$. Dengan demilkian terdapat pengaruh yang signifikan dari lima dimensi kepribadian secara keseluruhan terhadap perilaku prososial pada mahasiswa Psikologi Islam UIN Raden Intan Lampung.

Langkah selanjutnya, peneliti mencoba melihat koefisien regresi dari masing-masing variabel independen. Telah dijelaskan sebelumnya, jika $\mathrm{p}<0,05$ maka koefisien regresi tersebut signifikan yang berarti variabel independen tersebut memiliki pengaruh yang signifikan terhadap kecenderungan perilaku prososial pada mahasiswa Psikologi Islam UIN Raden Intan Lampung. Adapun besarnya koefisien regresi dari masing-masing variabel independen terhadap perilaku prososial dapat dilihat pada tabel berikut: 


\section{Tabel 9.}

Koefisien Regresi

\begin{tabular}{|c|c|c|c|c|c|}
\hline \multirow[t]{2}{*}{ Model } & \multicolumn{2}{|c|}{$\begin{array}{l}\text { Unstandardized } \\
\text { Coefficients }\end{array}$} & \multirow{2}{*}{$\begin{array}{c}\begin{array}{c}\text { Standardize } \\
\text { d } \\
\text { Coefficients }\end{array} \\
\text { Beta }\end{array}$} & \multirow[t]{2}{*}{ Sig. } & \multirow[t]{2}{*}{ Ket } \\
\hline & B & $\begin{array}{c}\text { Std. } \\
\text { Error }\end{array}$ & & & \\
\hline (Constant) & $\begin{array}{r}34,17 \\
2\end{array}$ & $\begin{array}{r}12,82 \\
0\end{array}$ & 0,000 & 0,009 & Signifikan \\
\hline openness & 1,376 & 0,565 & 0,252 & $\begin{array}{c}0,01 \\
7\end{array}$ & $\begin{array}{c}\text { Signifika } \\
\mathrm{n} \\
\text { Tidak }\end{array}$ \\
\hline $\begin{array}{c}\text { coscientiousnes } \\
s\end{array}$ & 0,604 & 0,461 & 0,126 & $\begin{array}{c}0,19 \\
3\end{array}$ & Signifikan \\
\hline extraversion & 0,666 & 0,665 & $-0,084$ & $\begin{array}{c}0,31 \\
9\end{array}$ & $\begin{array}{c}\text { Tidak } \\
\text { Signifikan }\end{array}$ \\
\hline agreeableness & 1,136 & 0,305 & 0,359 & $\begin{array}{c}0,00 \\
0\end{array}$ & $\begin{array}{l}\text { Signifikan } \\
\text { Tidak }\end{array}$ \\
\hline neuroticism & 0,629 & 0,428 & 0,130 & $\begin{array}{c}0,14 \\
5\end{array}$ & Signifikan \\
\hline
\end{tabular}

Berdasarkan koefisien regresi pada tabel di atas, dapat diketahui persamaan regresi yang memiliki pengaruh signifikan adalah pada dua variabel yakni pada dimensi kepribadian openness dan agreeableness dengan taraf signifikansi $\mathrm{p}<0,05$. Hal ini berarti dari lima hipotesis terdapat dua yang diterima. Penjelasan dari masing-masing variabel independen dapat dijabarkan sebagai berikut:

a. Variabel openness diperoleh nilai koefisien regresi sebesar 1,376 dengan signifikansi sebesar 0,017 (sig. < 0,05). Hal ini menunjukkan bahwa variabel openness pada dimensi kepribadian big five secara positif dan signifikan mempengaruhi perilaku prososial. Artinya, semakin tinggi variabel openness pada dimensi kepribadian big five maka semakin tinggi tingkat perilaku prososial

b. Variabel coscientiousness diperoleh nilai koefisien regresi sebesar 0,604 dengan signifikansi sebesar 0,193 (sig. > 0,05). Hal ini menunjukkan bahwa variabel coscientiousness pada dimensi kepribadian big five tidak mempengaruhi perilaku prososial.

c. Variabel extraversion diperoleh nilai koefisien regresi sebesar 0,666 dengan signifikansi sebesar 0,319 (sig. > 0,05). Hal ini menunjukkan bahwa variabel extraversion pada dimensi kepribadian big five tidak mempengaruhi perilaku prososial. 
d. Variabel agreeableness diperoleh nilai koefisien regresi sebesar 1,136 dengan signifikansi sebesar 0,000 (sig.< 0,05 ). Hal ini menunjukkan bahwa variabel agreeableness pada dimensi kepribadian big five secara positif dan signifikan mempengaruhi perilaku prososial. Artinya semakin tinggi variabel agreeableness pada dimensi kepribadian big five maka semakin tinggi perilaku prososial.

e. Variabel neuroticism diperoleh nilai koefisien regresi sebesar 0,629 dengan signifikansi sebesar 0,145 (sig. > 0,05). Hal ini menunjukkan bahwa variabel neuroticism pada dimensi kepribadian big five tidak mempengaruhi perilaku prososial.

Penelitian ini bertujuan untuk mengetahui adakah hubungan antara Perilaku Prososial dan Kepribadian big five pada mahasiswa Psikologi Islam Fakultas Ushuluddin Universitas Islam Negeri Bandar Lampung. Penelitian ini menggunakan teknik analisis regresi berganda untuk melihat ada tidaknya hubungan antara variabel bebas dengan variabel terikat. Proses analisis tersebut menggunakan bantuan program SPSS for windows 22.0.

Peneliti menggunakan sebanyak 100 mahasiswa Psikologi Islam untuk dijadikan sampel penelitian. Teknik sampling yang digunakan untuk pengambilan sampel dalam penelitian ini yaitu proportional stratified random sampling. Hasil yang diperoleh kemudian dilakukan kategorisasi berdasarkan data penelitian yang diperoleh dari keduaa variabel tersebut. Terdapat 80 mahasiswa (80\%) yang memiliki perilaku prososial tinggi. Perilaku Prososial pada mahasiswa Psikologi Islam dengan kategori tinggi tersebut dapat menggambarkan bahwa mahasiswa mempunyai perilaku prososial yang baik.

Selanjutnya, sebagian besar mahasiswa memiliki kepribadian openness yang tergolong sedang dengan jumlah sebanyak 82 mahasiswa atau setara 82\%. Sebanyak 64 mahasiswa atau 64\% memiliki kepribadian conscientiousness yang tergolong tinggi. Pada dimensi extraversion, keseluruhan mahasiswa atau sebanyak 100 mahasiswa memiliki kepribadian extraversion yang tergolong tinggi. Pada dimensi kepribadian agreeableness, terdapat 79 mahasiswa atau 79\% yang tergolong memiliki kepribadian agreeableness tinggi. Kategorisasi dimensi kepribadian neuroticism, sebanyak 74 mahasiswa atau \% tergolong memiliki kepribadian neuroticism yang sedang.

Berdasarkan hasil penelitian, maka hipotesis dalam penelitian ini dapat diterima yaitu bahwa kepribadian big five secara signifikan 
sebesar 38\% dapat mempengatuhi perilaku prososial sedangkan $62 \%$ sisanya dipengaruhi oleh variabel lain di luar penelitian ini. Ada hubungan yang positif dan signifikan antara dimensi kepribadian openness dan perilaku prososial sehingga hipotesis alternatif 1 diterima. Hasil tersebut menunjukkan bahwa mahasiswa Psikologi Islam yang memiliki kepribadian yang baik, yakni dengan openness memiliki pemikiran yang luas, terbuka terhadap orang lain, berpandangan luas dan memiliki kreatifitas akan cenderung dapat berperilaku prososial terhadap orang lain. Tidak ada hubungan yang negatif dan signifikan antara dimensi kepribadian conscientiosness dan perilaku prososial sehingga hipotesis alternatif 2 ditolak. Tidak ada hubungan yang negatif dan signifikan antara dimensi kepribadian extraverison terhadap perilaku prososial sehingga hipotesis alternatif 3 ditolak.

Ada hubungan yang positif dan signifikan antara dimensi kepribadian agreebleness dan perilaku prososial sehingga hipotesis alternatif 4 diterima. Hasil tersebut menunjukkan bahwa mahasiswa Psikologi Islam dengan kepribadian agreebleness yang baik yakni memiliki karakteristik terus terang, percaya diri, berhati lembut, baik hati, mudah memaafkan kesalahan orang lain dan ikhlas dalam melakukan suatu hal seperti membantu orang yang sedang kesusahan. Tidak ada hubungan yang negatif dan signifikan antara dimensi kepribadian neuroticism dan perilaku prososial sehingga hipotesis alternatif 5 ditolak.

\section{Kesimpulan dan Saran}

\section{a. Kesimpulan}

Berdasarkan hasil penelitian yang telah dilakukan, maka dapat diambil kesimpulan sebagai berikut:

1. Ada hubungan yang positif dan signifikan antara dimensi kepribadian openness dan perilaku prososial sehingga hipotesis alternatif 1 diterima. Oleh karenanya semakin tinggi dimensi kepribadian openness, maka semakin tinggi perilaku prososial pada mahasiswa Psikologi Islam. Sebaliknya semakin rendah dimensi kepribadian openness, maka semakin rendah perilaku prososial pada mahasiswa Psikologi Islam.

2. Tidak ada hubungan yang negatif dan signifikan antara dimensi kepribadian conscientiosness dan perilaku prososial sehingga hipotesis alternatif 2 ditolak. 
3. Tidak ada hubungan yang negatif dan signifikan antara dimensi kepribadian extraverison terhadap perilaku prososial sehingga hipotesis alternatif 3 ditolak.

4. Ada hubungan yang positif dan signifikan antara dimensi kepribadian agreebleness dan perilaku prososial sehingga hipotesis alternatif 4 diterima. Oleh karenanya semakin tinggi dimensi kepribadian agreebleness, maka semakin tinggi perilaku prososial pada mahasiswa Psikologi Islam. Sebaliknya semakin rendah dimensi kepribadian agreebleness, maka semakin rendah perilaku prososial pada mahasiswa Psikologi Islam.

5. Tidak ada hubungan yang negatif dan signifikan antara dimensi kepribadian neuroticism dan perilaku prososial sehingga hipotesis alternatif 5 ditolak.

\section{b. Saran}

Berdasarkan hasil penelitian yang telah peneliti laksanakan, saran yang dapat peneliti sampaikan adalah sebagai berikut:

1. Bagi subjek penelitian yakni mahasiswa Psikologi Islam Fakultas Ushuluddin dan Studi Agama Universitas Islam Negeri Raden Intan Lampung pada mahasiswa diharapkan mampu berinteraksi dengan orang lain, disiplin, tidak emosional sehingga mampu mengembangkan kepribadian kearah yang positif sehingga akan meningkatnya dimensi kepribadian conscientousness extraversion dan neuroticim. Mengolah karakter extraversion, agar dapat dimanfaatkan secara lebih positif seperti perhatian pada orang lain, ceria, lebih banyak berkomunikasi pada orang lain, ikut serta dalam organisasi khususnya kegiatan suka relawan, dapat lebih semangat dalam menjalankan aktifitas sehari - hari sehingga dapat meningkatkan perilaku prososial.

2. Bagi kampus diharapkan dapat lebih sering mengadakan kegiatan organisasi sukarelawan dengan harapan dapat meningkatkan perilaku prososial pada mahasiswa.

3. Bagi peneliti dapat mempertimbangkan lagi faktor yang mempengaruhi selain adanya kepribadian big five, contoh hal yang mungkin dapat digunakan seperti distress, rasa empati, dan religiusitas. Selain itu, pengambilan sampel besar juga dapat dilakukan agar dapat meningkatkan derajat kualitas penelitian, serta akan lebih baik jika peneliti mengawasi 
secara langsung dan fokus saat pengambilan data penelitian sehingga subjek yang kurang mengerti mengenai aitem pertanyaan dapat ditanyakan secara langsung.

\section{Referensi}

Baron, R. A., \& Byrne, D. (2005). Psikologi sosial (10 ${ }^{\text {th }}$ ed). Jakarta: Erlangga.

Caprara, G. V., \& Cervone, D. (2000). Personality: Determinants, dynamics and potentials. UK: Cambridge University Press.

Dayakisni, T. \& Hudaniah. (2009). Psikologi sosial. Malang: UMM Press.

Feist, J . \& Feist, G. J., (2009). Teori kepribadian. Jakarta: Salemba. Humanika.

Hartaji, D. A., (2012). Motivasi berprestasi pada mahasiswa yang berkuliah dengan jurusan pilihan orang tua (Skripsi yang Tidak Diterbitkan). Fakultas Psikologi Universitas Gunadarma, Depok.

Hurlock, E. B., (2004). Psikologi perkembangan suatu pendekatan sepanjang rentang kehidupan. Surabaya: Erlangga.

Kenrick. (2010). Social psychology: Goals in interaction $\left(4^{\text {th }}\right.$ ed). United States: Pearson

McCrae, R. R., (2011). 5 years of progress: A reply to block. Journal of Research in personality, $35: 108-113$.

Mussen, P. H., (2002). Perkembangan dan kepribadian Anak. Jakarta: Arcan.

Nugrahini, R. I. S., (2016). Pengaruh tipe kepribadian the big five dengan perilaku prososial pada remaja, (Skripsi Tidak Diterbitkan). Fakultas Psikologi Universitas Muhammadiyah Malang, Malang.

Pervin, L. A. Cervone, D., \& John, O. P. (2005). Personality : theory and research. $\mathrm{NJ}$ : Wiley.

Sears, D.O, Freedman, J.L, \& Peplau, L.A. (2001). Psikologi Sosial Jilid, (2 ${ }^{\text {th }}$ ed) Jakarta: Erlangga

Shaffer, D. R. (2000). Social and personality development. USA: Wadsworth, Thompson Learning, Inc. 